\title{
A CROSS-CULTURAL STUDY OF GLOBAL BRANDS ADVERTISING STRATEGIES IN IRAN
}

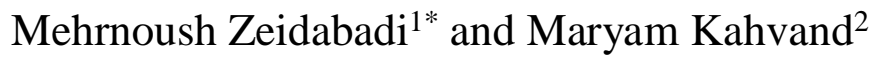 \\ ${ }^{1}$ Azad University, Tehran, \\ ${ }^{2}$ Faculty of Visual Arts, Tehran University of Art
}

\begin{abstract}
The success rate of international brands in the global market is affected by many factors, one of the most important of which is culture. These days, advertisements which can be adapted to meet the cultural needs of the community will be far more effective. Therefore, the researchers have studied three international outdoor advertising in Iran contributed to cultural differences from the perspective of Hall and Hofstede cultural theories. In the process of this research, which is considered Quasi-quantitative, a questionnaire was developed based on the indexes of the Hofstede and Hall models and filled in by marketing and visual communication specialists. The results indicate that "Clear" in the "indulgence" and "power distance" indicators of the Hofstede model and "non-verbal communication" indicator of the Hall model had a score higher than 5 and L'Oréal had the highest score of 5.66 in the Hall model of "being". Signal, was able to score 5.08 and 5.06 in Hofstede's dimension of "collectivism" and Hall's dimension of "indirectness", respectively. The results show that "Clear" follow the Hall and Hofstede models more than two other brands and "being" and "femininity" are the indicators which are considered more than other indicators in advertisements of all three brands.
\end{abstract}

Keywords: Cross-culture, Cultural differences, Hall and Hofstede models, Out-door Advertising

\section{Introduction}

The status of different countries in the global economy is largely influenced by the quantity and quality of their presence in the advertising industry. The effective introduction of a brand into the world market is one of the most important steps in having a successful economy and it is impacted by many factors. One of which is culture that has an impact on the success of brands in the foreign market (Benedict and Steenkamp, 2011). Culture is being expressed in different ways. Margaret Mead (1951) defines a culture which has been accepted by many scholars. She believes that culture is a collection of learned behaviours, beliefs, habits and traditions that are common among a group of individuals and are consistently learned and practised by others who enter that society. In most cases, the nationality of a person represents their culture because it creates the social norms of a nation. Each society has its own cultural elements and considerations that can be observed in language, religion, values, customs and etcetera. The need to examine the role of culture and its usage in international advertising can be still noticed by considering the increasing attention to cultural factors in recent years and the effect of these factors on the advertising methods of brands in different countries (De Mooji, 1998). Nowadays, advertisements which can adapt themselves to the communities' cultural charactristics are more effective (The same).

Regarding the above matter and investigations conducted by the researchers in this area, it is observed that no research has not been conducted for identifying and reviewing the advertising strategies of successful international brands in Iran from a cultural point of view. Therefore, the need for advertising and marketing communication industry to know how to communicate more effectively with the global audience is still considered important. As a result, the researchers conducted research into international brands and their outdoor advertising in Iran while paying attention to cultural differences from Hall and Hofstede's view point. 


\section{Literature review}

Understanding the cultural differences is often considered a prerequisite for having successful international communication because of the fact that cultural values and advertising have a great impact on each other. Consumers who grew up in the same culture have similar cultural values and beliefs. They respond to advertising based on their cultural norms which is the reason why social values and cultural characteristics of the audience may restrict the choice of advertising styles used in a particular culture. To succeed in advertising campaigns, we need to make a proper analysis of cultural differences (Zhang and Neelangkavil, 1997).

Hall believes that culture, which determines how the world is perceived, is responsible for what the person ignores or pays attention to and most cultures lie out of the control of human being (Hall,1976). According to Geert Hofstede and Geert John Hofstede, culture is a general mental planning which distinguishes members of a group from others (Hofstede and Hofstede, 2005, p.4). Kroeber and Kluckhohn argue that culture includes explicit and implicit patterns of behaviour that are learned and transmitted through symbols which are exclusively human achievements. On the one hand, cultural systems can be considered as products of social actions and, on the other hand, the contingent factor of future actions. (Kroeber and Kluckhohn, 1952). Rick points out that over the past two decades, one of the biggest challenges in global marketing has been connecting people with different cultural backgrounds (De Mooji, 1998). In such a situation, expanding one's horizons in terms of cultural designs is necessary to meet the needs and aspirations of the society, which becomes more diverse every day. Yoon (2003) holds the view that all dimensions of a culture are reflected in advertising at various levels and commercial advertising reflects the culture of a society. Consequently, since the late 1980s, various scholars have studied the relation between cultural values and commercial advertising. Therefore, some research has been conducted into three international beauty and personal care brands (Clear, L'Oréal and Signal) in Iran which answers the following question:

\section{How do cultural differences contribute to advertising strategies in Iran?}

\section{Theoretical Framework}

\section{Cultural classification}

As each nation has its own culture, it is constantly in contact with other cultures. In fact, our daily life is crosscultural and we always interact and coexist with foreign people, products and services. Moreover, all of us are guided by a unique set of rules, values, behaviour and habits that makes us identifiable, and at the same time distinguishable from others (Paranhos et al, 2001). In the book "Intercultural Competence", Lusting and Koester claim that our quality of life, whether at the personal or professional level, is relevant to our ability to communicate effectively with other cultures more than anything else. (Lusting and Koester, 2010, p.11). Bennett believes that some cultural differences are in decline, while some of these differences require negotiation and finding solutions. In fact, adapting to a culture implies adding new behavioural abilities to our own culture. Cultural adaptation derives from a person's desire to obtain common meanings in business, education abroad, communication and success in other cultural situations (Bennett, 2009, p.127).

Many cultural models have been proposed by scholars. Among all, Hall and Hofstede models were selected as the theoretical framework of this research. Hofstede's theory is considered to be one of the most popular cultural views in the field of international marketing, and the concept presented by him is widely accepted in this regard. These conditions, albeit less, apply to Hall's theory (Holden, 2004). The main aspect of both Hofstede and Hall models can be considered as the native and regional significance of culture. The Hofstede model is influenced by the theory of value orientation, which was first introduced by Kluckhohn. Kluckhohn model was based on the functionalism theory, which had a significant impact on Hall's theory (Roger and Hart, 1988). As a result, the researchers used both models to achieve a comprehensive model of research. Besides, as Iran was studied by Hofstede specifically, indicators are available to Iran. 


\section{Hall model}

Hall divided cultures into two categories: high context cultures and low context cultures. Hall (1976) holds the opinion that high context cultures rely on symbols and non-verbal ques, while in low context cultures, the messages are expressed clearly and are often written. There is transparency in transmitting messages and the words are carefully selected and can convey the concept without ambiguity. people of North America, Australia, and Western Europe have such a culture. In countries with a high context culture there is no transparency in the transmission of messages, and signs and symbols are used. Iran, most other Asian countries, most Arab countries and Latin America have high context cultures (Sanyal, 2001, p.63). There is no ambiguity in these messages, and meanings are often defined as codes. Besides, relationships are clear in these cultures (Zaharana, 1995).

In high context cultures, non-verbal communication is very important, and even yes or no as the answer, can be ambiguous and the receiver can only understand the meaning of the message by understanding the signs of the context. As a whole, in high context cultures, receiver is responsible for understanding messages more than the sender does. However, in low context cultures, the task of transferring the meaning is the sender's responsibility (The same). In regard to the definitions given in high and low cultures, cultural elements of time, verbal and non-verbal, direct and indirect, doing and being, linear and non-linear, and space in high and low context cultures will be examined. Dimensions of the Hall model are summarized in the table below.

Table 1 : Summary of Hall's high and low context cultures characteristics.

\begin{tabular}{|c|c|c|}
\hline Dimensions & High context cultures & Low context cultures \\
\hline Time & $\begin{array}{l}\text { Multidimensional culture } \\
\text { Flexible method based on each person's } \\
\text { characteristics } \\
\text { Do many things at once } \\
\text { Delay is accepted (Loosmore et al, 1999) }\end{array}$ & $\begin{array}{l}\text { Single-dimensional culture } \\
\text { Concentration the job at hand } \\
\text { Do one thing at a time } \\
\text { Delay is not accepted (Schermerhorn } \\
\text { et al, 2011) }\end{array}$ \\
\hline $\begin{array}{l}\text { Verbal / Non-verbal } \\
\text { communication }\end{array}$ & $\begin{array}{l}\text { Written communication is used } \\
\text { Body language is very important } \\
\text { Silence as a mean of communication } \\
\text { (Loosmore et al, 1999) }\end{array}$ & $\begin{array}{l}\text { Verbal communication is used There is } \\
\text { little scope for silence (Loosmore et al, } \\
\text { 1999) }\end{array}$ \\
\hline Direct/Indirect & $\begin{array}{l}\text { Indirect } \\
\text { Expression of emotion (Zaharana, 1995) } \\
\text { Details are important (Sanyal, 2001) }\end{array}$ & $\begin{array}{l}\text { Direct } \\
\text { The facts, methods, and expectations } \\
\text { are accurately expressed } \\
\text { Avoid emotional speaking (Zaharana, } \\
\text { 1995) }\end{array}$ \\
\hline Space & People have less privacy (Sanyal, 2001) & $\begin{array}{l}\text { People have their own privacy } \\
\text { (Sanyal, 2001) }\end{array}$ \\
\hline Being/Doing & $\begin{array}{l}\text { Being } \\
\text { Who you are is more important than what } \\
\text { you do (Robbins et al, 2007) }\end{array}$ & $\begin{array}{l}\text { Doing } \\
\text { Words and actions have the same } \\
\text { meaning } \\
\text { Avoiding symbolic expression } \\
\text { (Robbins et al, 2007) }\end{array}$ \\
\hline Linear/Nonlinear & $\begin{array}{l}\text { Non-linear } \\
\text { Do things simultaneously } \\
\text { Focus on images more (Zaharana, 1995) } \\
\text { Advertising is often expressed indirectly } \\
\text { and implicitly, with modest and vague } \\
\text { terms (Singh et al, 2005) }\end{array}$ & $\begin{array}{l}\text { Linear } \\
\text { Do things individually and one after } \\
\text { the other } \\
\text { Emphasis on words (Zaharana, 1995) } \\
\text { The effectiveness of advertisements } \\
\text { with aggressive methods } \\
\text { (Singh et al, 2005) }\end{array}$ \\
\hline
\end{tabular}




\section{Hofstede model}

In the late 1970s, Geert Hofstede conducted research on 116,000 IBM employees in 40 countries, including Iran (Hofstede, 1997). Hofstede's studies are one of the most comprehensive researches on how values in the workplace are affected by culture. Hofstede describes six factors as national cultural variables as follows:

Table 2: Summary of Hofstede's cultural dimensions.

\begin{tabular}{|c|c|c|}
\hline Dimensions & Features & \\
\hline Individualism & $\begin{array}{l}\text { Individualism } \\
\text { Taking care of themselves and their } \\
\text { immediate family } \\
\text { Looking for personal goals } \\
\text { Looking for fame } \\
\text { Loosely-knit social family (Javenppa et } \\
\text { al, 1999) }\end{array}$ & $\begin{array}{l}\text { Collectivism } \\
\text { Attention to the group and take aside of } \\
\text { the group } \\
\text { Looking for group goals } \\
\text { Tightly-knit social framework } \\
\text { Trust to in-groups (Javenppa et al, 1999) }\end{array}$ \\
\hline Power distance & $\begin{array}{l}\text { More inequality } \\
\text { High power distance } \\
\text { Concentration is common Hierarchical } \\
\text { order is accepted (Illagan, 2009) }\end{array}$ & $\begin{array}{l}\text { Less inequality } \\
\text { The value of equality of individuals } \\
\text { Hierarchical order is not } \\
\text { accepted (Illagan, 2009) }\end{array}$ \\
\hline Masculinity & $\begin{array}{l}\text { Masculine } \\
\text { The importance of training and being up } \\
\text { to date (Hofstede, 2001, p.281) } \\
\text { Performance for achievement, heroism, } \\
\text { assertiveness and material } \\
\text { reward (Hofstede, 1994, p.6) } \\
\text { Social gender roles are distinct (De Mooji } \\
\text { and Hofstede, 2002) } \\
\text { Focus on material success } \\
\text { (Illagan, 2009, p.22) }\end{array}$ & $\begin{array}{l}\text { Feminine } \\
\text { Concerned with the quality of life } \\
\text { Maintain personal bonds } \\
\text { Weak are cared } \\
\text { Cooperation } \\
\text { People are important (Hofstede, 1994, } \\
\text { p.6) } \\
\text { Social gender roles overlap } \\
\text { Quality of life is important (Illagan, 2009, } \\
\text { 22) }\end{array}$ \\
\hline $\begin{array}{l}\text { Uncertainty } \\
\text { Avoidance }\end{array}$ & $\begin{array}{l}\text { High degree of uncertainty } \\
\text { Low resistance to changes } \\
\text { Do not afraid of the future (Illagan, 200, } \\
\text { p.21) }\end{array}$ & $\begin{array}{l}\text { Ambiguity } \\
\text { Stronger resistance against changes } \\
\text { Fear of the future (Illagan, 200, p.21) }\end{array}$ \\
\hline $\begin{array}{l}\text { Long-term } \\
\text { orientation }\end{array}$ & $\begin{array}{l}\text { Long term } \\
\text { Value of saving and perseverance } \\
\text { (Hofstede and Hofstede, 2005, p.210) }\end{array}$ & $\begin{array}{l}\text { Short term } \\
\text { Virtuoso } \\
\text { Importance of the present and the past } \\
\text { Respect for traditions and social } \\
\text { obligations } \\
\text { (Hofstede and Hofstede, 2005, p.210) }\end{array}$ \\
\hline Indulgence & $\begin{array}{l}\text { Indulgence } \\
\text { Free relationships } \\
\text { The pleasure of life and satisfaction } \\
\text { A high level of happiness is reserved for } \\
\text { people who seek joy and frenetic } \\
\text { activities without feeling guilty (Hofstede } \\
\text { and Hofstede, 2005, p.210) }\end{array}$ & $\begin{array}{l}\text { Restraint } \\
\text { Suppressing pleasures } \\
\text { Strict social norms } \\
\text { Constrained by social laws and } \\
\text { prohibitions (Hofstede and Hofstede, } \\
2005, \text { p.210) }\end{array}$ \\
\hline
\end{tabular}




\section{Iran from cultural dimensions}

The results of Hofstede's studies in Iran are briefly summerized below:

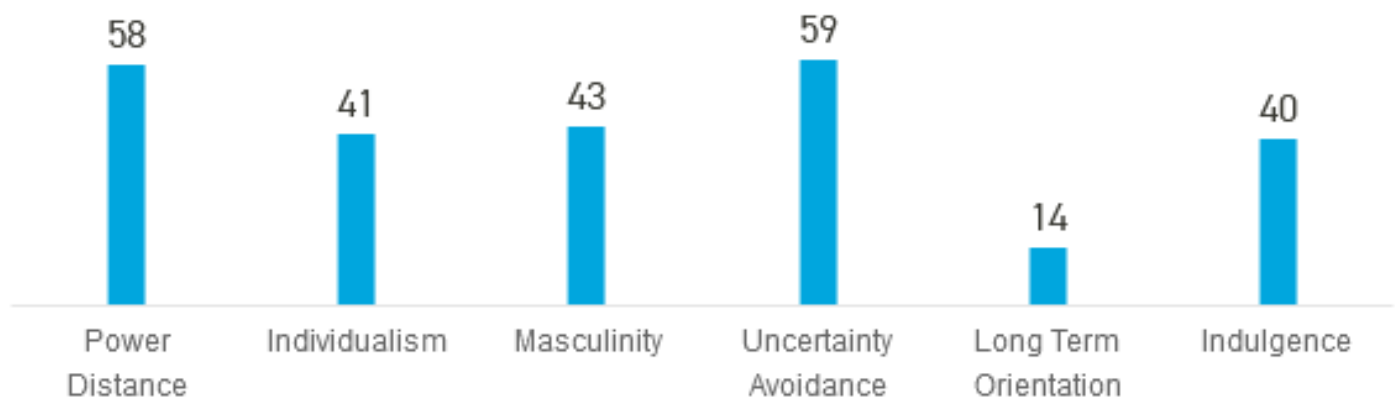

Figureb1: Iran's scores in Hofstede studies

\section{Power Distance}

Iran has gained an intermediate score of 58 in the power distance index and considered a hierarchical society. This means that people have accepted the hierarchical order, so that each person has a position that does not require further justification. The hierarchy in an organization reflects inherent inequalities. Centralization is popular, subordinates expect they should and should not be told what to do, and the ideal boss is autocrat but benevolent (Hofstede website, 2017).

\section{Individualism/ Collectivism}

Iran with a score of 41 is a collectivism community. This means announcing a long-term commitment to members of the group, as a family, extended family, or extended relationships. Loyalty in a collectivist culture is very important and includes most social rules and regulations. In these types of societies, strong relationships are established and everyone accepts the responsibility of fellow members of the group. In collectivist societies, offence and crime lead to shame and loss of face. employer-employee relationships are perceived in moral term (like a family bond), decisions about recruitment and promotion take account of the employee's in-group (The same).

\section{Masculinity/ Femininity}

Iran has a score of 43 in this regard, which is why the society is relatively a feminine society. In feminine countries, focus is on "working in order to live". Managers try to reach consensus and agreement on values like equality, solidarity, and quality in their working life. Conflicts are resolved by compromise and negotiation. Motivations (incentives) such as free time and flexibility are preferred (The same).

\section{Uncertainty Avoidance}

Iran scores 59 in this regard and therefore has a high preference for uncertainty avoidance and risky situations. Countries with high level of uncertainty maintain rigid codes of beliefs and behaviours and intolerant of unorthodox behaviour and ideas. In these cultures, there is an emotional need for having rules (even if the rules 
have no function). People have motivation and inner urge to be busy and working hard, precision and punctuality are the norm. Innovation is confronted with resistance and security is an important element in individual motivation (The same).

\section{Short/ Long Term Oriented}

A very low score of 14 in Iran indicates a strong and normative cultural orientation. The people of these societies are serious about creating absolute truth. They are normative in their thinking. They respect traditions and have very little willingness to save in the future and focus on achieving fast results (The same).

\section{Indulgence/ Restraint}

A low score of 40 shows that Iran has a culture of restraint. Societies with a low score in this dimension tend to be pessimistic. In addition, societies with a radical tendency do not emphasize leisure time and the satisfaction of their desires are limited. Individuals with this tendency think their actions are limited and restrained by social norms and feel that their abandonment of desires and extremes are wrong (The same).

\section{Methodology}

This research is part of a descriptive study conducted in a survey. In the process of this research, which is considered a quasi-quantitative research group, the literature on the subject was studied first and based on the indexes of the Hofstede and Hall models, the questionnaire was developed by the researchers. The researchers also participated in the process of filling in the questionnaire in order to respond properly to the comments or questions of the respondents. The questions were formulated based on literature findings related to the Hall and Hofstede models (Tables 1 and 2). Since Iran has a high context culture, only the high context cultural indicators, which are presented in Table 1, were used. Moreover, the only indicators of Hofstede model which are related to Iran, namely collectivism, femininity, high power distance, ambiguity, short-term orientation, and restraint, were used in designing the questionnaire. Given that the questionnaire was revised and reviewed by the faculty members at the mentioned stage, and its face validity was confirmed. For checking reliability, Cronbach's method also proved its reliability. The result is attached (Attachment No. 1). If respondents regard grade five or higher for questions related to each of the indicators, means more adaptation of studied advertisements to the Hall and Hofstede models, and if the score is less than five, means less adaptation to these two models. The population chosen for this study were marketing and visual communication specialists. considering the purpose of this research, experts were chosen based on the field of their specialties (marketing and visual communication), scientific background (at least three articles related to the subject), work experience (at least three years teaching experience), commercial experience (at least three years of related commercial experience), being a faculty member, and finally familiarity with the research models. Regarding to the number of faculty members in the fields of business management and visual communication in four prestigious universities in Tehran (45 faculty members), 20 persons were chosen with the criteria, 10 faculty members in business management and 10 faculty members in visual communication. Finally, the questionnaires were distributed among all members of the sampling frame.

Billboard advertising was also selected as a form of outdoor advertising. Based on the research carried out by Atefeh Frouzan (2014) in her thesis titled "Ranking of various environmental advertisements in the city of Tehran using AHP technique"; She claims that in Tehran, billboard advertising is considered the most effective type of outdoor advertising. The second reason for selecting billboard is the researcher's personal interest as well as her field of work. It should be noted that no research on the fact that which type of advertising is the most popular one in Iran has been conducted. According to Clutch website (2017), billboard advertising is in fourth place after television, print, and radio advertisements, and before online advertising in the United States. The status of outdoor advertising in Iran is very different, and companies in Iran use this media as a mean of 
displaying their power and spend a few billion dollars on it (Esmaelee, 2018). Therefore, first the 22 areas of Tehran were surveyed in terms of billboard numbers and their statistics were obtained from the municipality by considering the number of billboard advertisements in each district. The areas with the most frequent number of billboards were selected and all of their billboards (from beauty and personal care brands) were collected and finally, based on the largest number of billboards, three brands (Clear, L'Oréal and Signal) were selected over the period. Each brand had two billboards in Tehran in 2017. Considering the fact that the questionnaire was designed from 1 to 10 , the result through averaging described whether these three brands follow the cultural differences from the viewpoint of Hall and Hofstede models or not.

\section{Research main question:}

How do cultural differences contribute to advertising strategies in Iran?

\section{Research hypothesis:}

H1: The advertising strategies of Clear, L’Oréal and Signal in Iran follow the Hall model.

H2: The advertising strategies of Clear, L'Oréal and Signal in Iran follow the Hofstede model.

\section{Results}

Based on the research methodology, 120 questionare were filled in. Each brand (Sigal, L'Oréal and Clear) has two billboards. Consequently, six questionares were filles in by each of 20 specialists. Collected data were analyzed by SPSS software. The results are shown below:

Table 3 :Comparison of Clear, L'Oréal and Signal advertisements base on Hall and Hofstede's cultural characteristics

\begin{tabular}{lll}
\hline Brands & Hall & Hofstede \\
\hline Clear & 4.76 & 4.52 \\
\hline L’Oréal & 4.42 & 4.55 \\
\hline Signal & 4.13 & 3.93 \\
\hline
\end{tabular}

The table above illustrates the value obtained for brands based on Hall and Hofstede cultural theories. As can be seen clearly, none of the selected brands achieve the proper place in terms of Hofstede and Hall's cultural dimensions. Indeed, in the design of the billboards of none of these brands, the Hall and Hofstede cultural indexes were not considered. The chart below shows the average of these brands in the Hall and Hofstede models. 


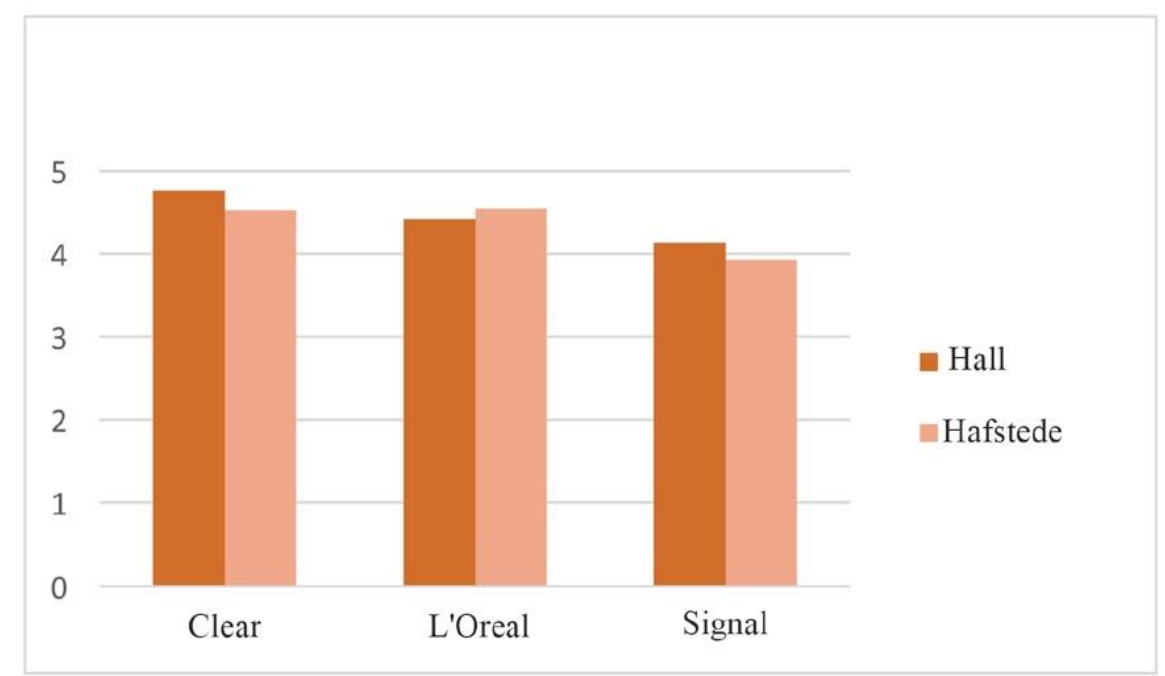

Figure 2: Comparison of Clear, L'Oréal and Signal advertisements base on Hall and Hofstede's cultural characteristics

\section{The status of brands based on Hall's cultural indicators}

Table 4:The average value obtained for brands based on Hall's cultural indicators.

\begin{tabular}{lllllll}
\hline Brand & Time & $\begin{array}{l}\text { Non-verbal } \\
\text { communication }\end{array}$ & Indirect & $\begin{array}{l}\text { Non- } \\
\text { linear }\end{array}$ & Being & Space \\
\hline Clear & 4.05 & 5.40 & 4.60 & 3.83 & 5.60 & 3.70 \\
\hline L'Oréal & 3.90 & 5.07 & 5.04 & 3.73 & 5.66 & 3.90 \\
\hline Signal & 2.80 & 4.28 & 5.06 & 3.66 & 3.90 & 3.58 \\
\hline
\end{tabular}

It can be seen that the highest score is the being index for L'Oréal, whereas the lowest score is the time index for signal. Clear and L'Oréal have the highest score in being index, while for Signal, the highest score is for the indirect index. The status of brands in terms of cultural dimensions of the Hall model is shown in the diagram below: 


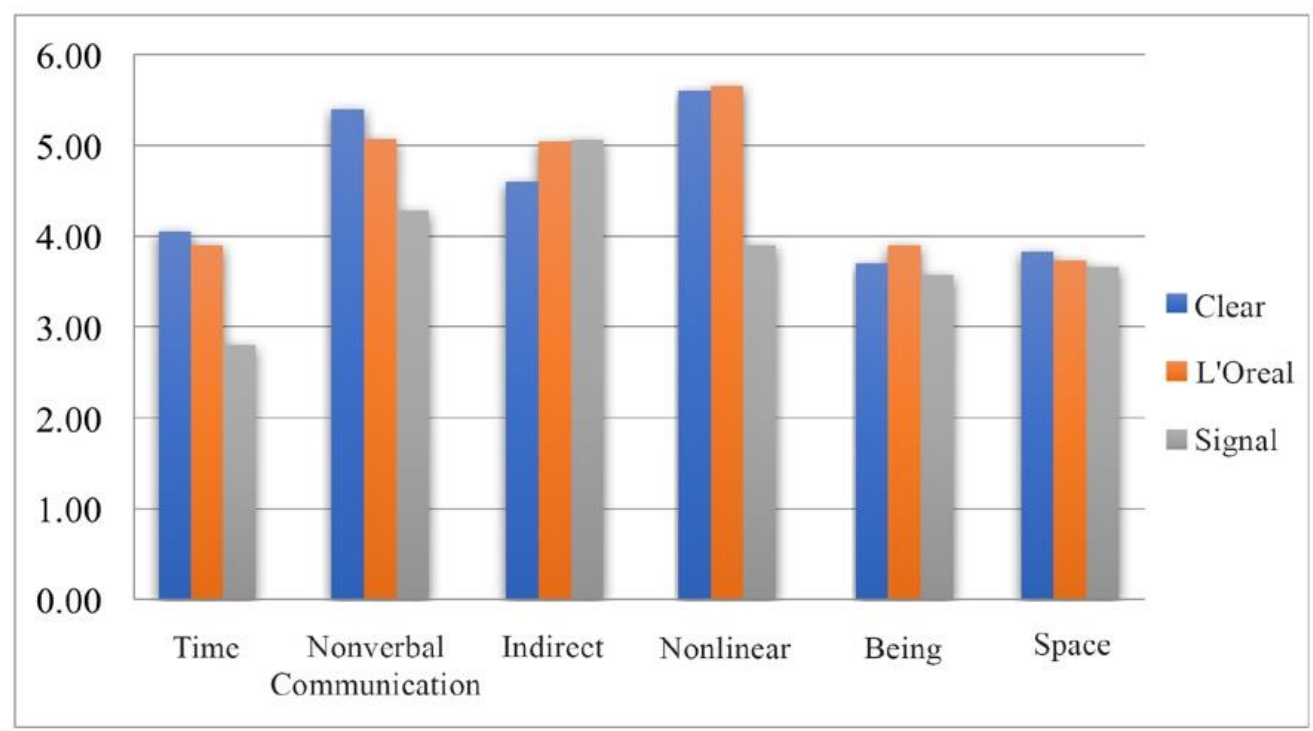

Figure 3: The average value obtained for brands based on Hall's cultural indicators.

Finally, being index was considered slightly more than non-verbal and indirect indexes by Clear, L'Oréal and Signal. This is while time is the index that received the least attention.

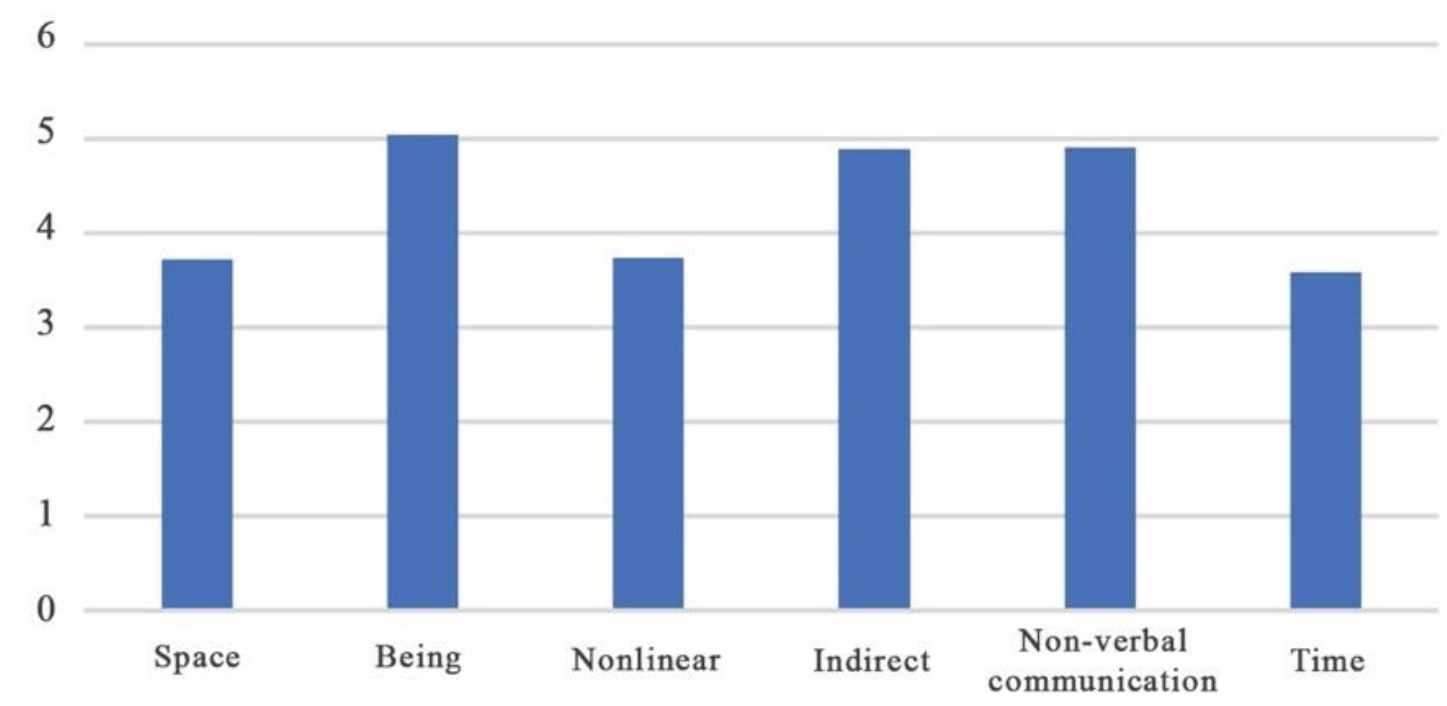

Figure 4: Comparison of Clear, L'Oréal and Signal advertisements base on Hall model.

Table 5: Comparison of Clear, L'Oréal and Signal advertisements base on Hall model.

\begin{tabular}{|c|c|c|c|c|c|c|}
\hline Brand & Time & $\begin{array}{l}\text { Non-verbal } \\
\text { communication }\end{array}$ & Indirect & Non-linear & Being & Space \\
\hline & 3.58 & 4.91 & 4.90 & 3.74 & 5.05 & 3.72 \\
\hline
\end{tabular}


The status of brands based on Hofstede's cultural indicators

Table 6:The average value obtained for brands based on Hofstede's cultural indicators.

\begin{tabular}{lllllll}
\hline Brand & $\begin{array}{l}\text { High } \\
\text { power } \\
\text { distance }\end{array}$ & Individualism & Femininity & $\begin{array}{l}\text { Uncertainty } \\
\text { avoidance }\end{array}$ & $\begin{array}{l}\text { Short term } \\
\text { orientation }\end{array}$ & restraint \\
\hline Clear & 5.20 & 4.80 & 4.86 & 3.80 & 4.55 & 5.40 \\
\hline L'Oréal & 4.29 & 4.61 & 4.91 & 3.02 & 4.82 & 4.83 \\
\hline Signal & 3.98 & 5.08 & 4.82 & 2.60 & 3.88 & 4.10 \\
\hline
\end{tabular}

Regarding to the above table, the highest average level for Clear is on restriction index and the lowest score is for the uncertainty avoidance index. For L'Oréal, the highest score is related to the femininity index, while for Signal, the highest score is on the index of collectivism. The status of these brands examined in the Hofstede's Indices is presented in the following graph.

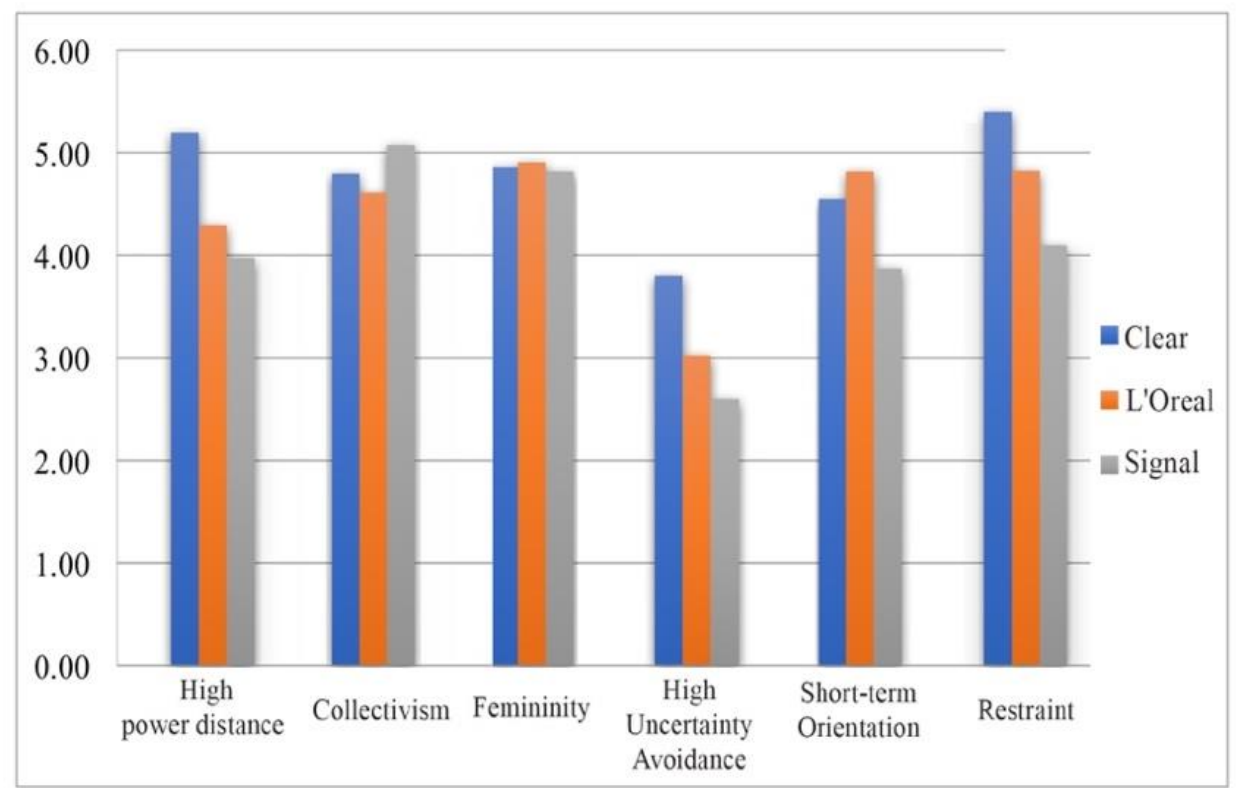

Figure 5:The average value obtained for brands based on Hofstede's cultural indicators.

Finally, the index of femininity is considered more than other indicators in advertisements of all three brands. After that, individualism, restraint and power distance gain the higher level respectively. Also, the uncertainty avoidance index has the lowest rank among the indicators observed on the basis of Hofstede's theory.

Table 7: Comparison of Clear, L'Oréal and Signal advertisements base on Hofstede model.

\begin{tabular}{lllllll}
\hline Brand & $\begin{array}{l}\text { High } \\
\text { power } \\
\text { distance }\end{array}$ & Individualism & Femininity & $\begin{array}{l}\text { Uncertainty } \\
\text { avoidance }\end{array}$ & $\begin{array}{l}\text { Short term } \\
\text { orientation }\end{array}$ & restraint \\
\hline 4.49 & 4.83 & 4.86 & 3.14 & 4.41 & 4.77 \\
\hline
\end{tabular}




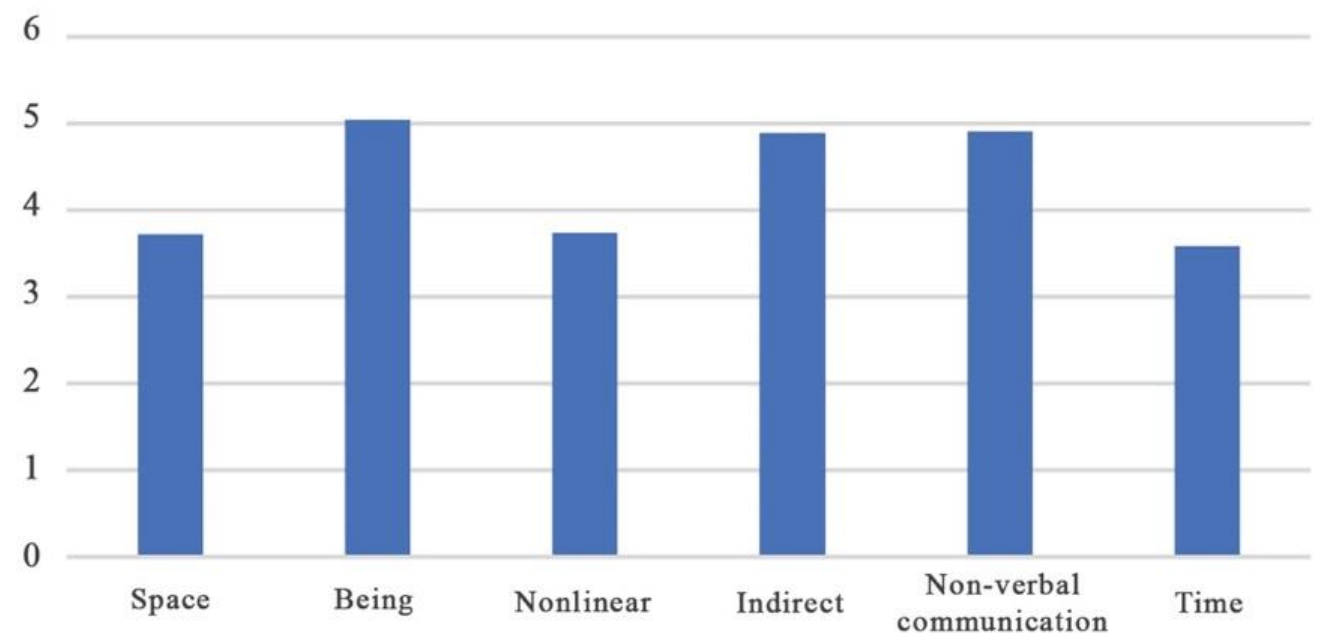

Figure 6 : Comparison of Clear, L'Oréal and Signal advertisements base on Hofstede model

\section{Conclusion}

These days, advertising is one of the most important, attractive, lucrative, and, at the same time, challenging industries. In fact, all advertisements are primarily aimed to market the product. As it was mentioned, considering the cultural differences is one of the important factors that can help companies and brands achieve more success in different societies. As a result, the researchers carried out research on three international brands for evaluating their concentration on cultural differences in their outdoor advertisements in Iran. Thus, two cross-cultural models were selected and based on the characteristics of those two models, the questionnaire was developed by the researchers. After designing and troubleshooting, the questionnaire was filled in by marketing and visual communication specialists, and the results were analyzed by SPSS software.

Considering the results, none of the mentioned brands were able to obtain five out of 10 , which means that they are not in conformity with two mentioned models. In Hofstede's indexes, the indulgence and power distance indexes for Clear are above five. Clear on the index of collectivism and L'Oréal on femininity index gained the highest level. Signal also gained the highest score on the index of collectivism. However, in general none of the brands were able to obtain a total of five points.

In the Hall model, none of the brands could obtain an average of five. In each of Hall's indexes, Clear earned the highest score in the being index and then using non-verbal communication. L'Oréal highest scores were for the being index, non-verbal and indirect indicators respectively. Clear also earned the indirect index highest score.

Finally, the index of femininity was considered more than other indicators in advertising of the three brands. Furthermore, the uncertainty avoidance index has the lowest rank among the indicators observed on the basis of Hofstede's theory. Moreover, in the Hall model, being index obtained the highest score by Clear, L'Oréal and Signal. This is while time is the index that received the least score.

Unfortunately, the results show that the cultural indicators of the Hall and Hofstede models are not fully compatible with the design of studied billboards. However, Clear gained more average than two others, and it seems to be more consistent with the models. Considering the importance of cultural issues, especially in the Middle East, further studies are needed in this regard, as it seems that paying attention to cross-cultural studies on advertising of the brand, as well as volume of sales of brands is effective. Nevertheless, this issue does not fit into this article and there is a need for a separate study in this regard. Due to scarce information about foreign 
companies and brands and their cross-cultural advertising in Iran, the results of this study can provide the basic information about the status of at least these three brands to other researchers.

\section{References}

Benedict, J. and Steenkamp, 2011, The role of national culture in international marketing research, International Marketing Review, 18(1), 30-44.

Bennett, J. M., 2009, Cultivating Intercultural Competence: A Process Perspective. Conceptualizing intercultural competence. Edited by: D. K. Dreadorff, The sage handbook of intercultural competence (California: Sage) pp. 121-140.

Clutch, How consumers view advertising: 2017 survey, Date of access: 05/02/2018 https://clutch.co/agencies/resources/how-consumers-view-advertising-survey-2017

De Mooji, M., 1998, Global Marketing and Advertising: Understanding Cultural Paradoxes (California, U.S.: Thousand Oaks).

De Mooji, M., and Hofstede, G., 2002, Convergence and divergence in consumer behavior: implications For International Retailing. Retailing, 78(1), 61-69.

De Mooji, M., Hofstede, G., 2010, The Hofstede model: applications to global branding and advertising strategy and research. Advertising, 29(1), 85-110.

Esmaelee, M., 2018, Inconsiderable, Jam-E-Jam, 9 May.

Forouzan, A., 2014, Ranking of various environmental advertisements in the city of Tehran using AHP technique, Master Of science thesis, Allameh Tabatabai University.

Hall, E.T., 1976, Beyond Culture (New York, U.S.: Garden City)

Hofstede Website, Iran cultural dimensions, Date of access: 17/05/2017

https://www.hofstede-insights.com/product/compare-countries/

Hofstede, G., 1994, Management scientists are human. Management Science, 40(1), 4-13.

Hofstede, G., 1997, Culture and Organizations: Software of The Mind (London, U.K.: McGrew-Hill)

Hofstede, G., 2001, Culture's Consequences (London, U.K.: Sage).

Hofstede, G., Hofstede, G. J., 2005, Cultures and Organizations: Software of The Mind (New York, U.S.: McGraw-Hill).

Holden, N., 2004, why marketers need a new concept of culture for the global knowledge economy. International Marketing Review, 21(6), 563-572.

Ilagan, S. V., 2009, Exploring the impact of culture on the formation of consumer trust in internet shopping. Master of arts thesis, Wyoming University, Laramie, United State.

Javenppa, S. L., Tractinsky, N., Saarinen, L. And Vitale, M., 1999, Consumer trust in an internet store: a crosscultural validation. Computer-Mediated Communication, 5(2).

Kroeber, A. L., Kluchhohn C., 1952, Culture: A critical review of concepts and definitions. Harvard University Peabody Museum of America Archeology and Ethnology.

Loosemore, M. and Al Muslmani, H. S., 1999, Construction project management in Persian Gulf: inter- cultural communication. Project Management, 17(2), 95-100.

Lusting, M., and Koester, J., 2010, Intercultural Competence: Interpersonal Communication Across Culture, (Boston, U.S.: Pearson).

MEAD, M., 1951, Cultural Patterns and Technical Change (Paris, France: UNESCO).

Paranhos, M. L., Damazio, V. and Meyer, M.R., 2011, Design and cultural diversity: contributions of crosscultural studies for the project of products and services to a plural world. Proceeding of the MX design conference, Mexico.

Robbins, S. P., Judge, T., 2007, Organizational Behavior (Boston, U.S.: Pearson).

Rojer, E. and Hart, B., 1998, Edward T Hall and the origins of the field of intercultural communication. Paper presented at meeting of the Nation Communication Association, New York. 
Sanyal, R., 2001, International Management: A Strategic Perspective (New Jersey, U.S.: Prentice-Hall).

Schermerhorn, J. R., Hunt J., Osborn, R. N., and Uhl-Bien, M., 2011, Organizational Behavior (New York, U.S.: Wiley).

Singh, N., Zhao, H., and Hu, X., 2005, Analyzing the cultural content of websites: a cross-national comparison of China, India, Japan and USA. International Marketing Review, 22(2), 129-146.

Yoon, H. C., 2003, With special reference to the images of elderly, The Asian Research Center for Religion and Social Communication, Date of access: 20/10/2015

Http://www.stjohn.ac.th/arc/Cultural

Zaharana, R. S., 1995, Understanding cultural preference of Arab communication pattern, Public Relation Review, 21(3), 241-255.

Zhang, Y., \& Neelankavil, J., 1997, The influence of culture on advertising effectiveness in China and the USA: a cross cultural study. European Journal of Marketing, 31(2), 134-149 
Mehrnoush Zeidabadi and Maryam Kahvand / A Cross-Cultural Study Of Global Brands ......

\section{Attachment 1}

The result of Cronbach's alpha test for measuring the reliability of the questionnaire

Case Processing Summary

\begin{tabular}{|rl|r|r|}
\hline & & \multicolumn{1}{|c|}{$\mathrm{N}$} & \multicolumn{1}{c|}{$\%$} \\
\hline Cases & Valid & 121 & 100.0 \\
& Excluded $^{\mathrm{a}}$ & 0 & .0 \\
& Total & 121 & 100.0 \\
\hline
\end{tabular}

a. Listwise deletion based on all variables in the procedure.

\section{Reliability Statistics}

\begin{tabular}{|r|r|}
\hline $\begin{array}{c}\text { Cronbach's } \\
\text { Alpha }\end{array}$ & N of Items \\
\hline .906 & 22 \\
\hline
\end{tabular}

